\title{
塩害環境下におけるコンクリート中への塩化物イオンの 浸透に関する解析的研究 \\ ANALYTICAL STUDY ON CHLORIDE PENETRATION INTO CONCRETE EXPOSED TO SALT-LADEN ENVIRONMENT
}

\author{
山田義智*, 大城＼cjkstart武**, 栘 田佳寛*** \\ Yoshitomo YAMADA, Takeshi OSHIRO and Yoshihiro MASUDA
}

\begin{abstract}
This paper presents an analytical method for simulating chloride-ion penetration into concrete exposed to salt-laden environment. Two RC test structures exposed for 7 and 12 years are used for investigating the characteristics of chloride-ion penetration. Evaluating the test results, new analytical method for the diffusion equation is proposed. This method considers various influences from important factors such as air-laden chlorides, carbonation of concrete, water cement ratio $(w / c)$, washing out and period. Comparing the analytical results with the field data, it is concluded that the proposed method gives excellent results and represents the characteristics of real phenomenon.
\end{abstract}

Keywords : boundary condition, air born chloride-ions, chloride-ion penetration, diffusion equation, finite element method, modified simplex method

境界条件, 飛来塩化物イオン, 塩化物イオン浸透, 拡散方程式, 有限要素法, 修正シンプレックス法

1.はじめに

海岸付近に建設された鉄筋コンクリート構造物では, 鉄筋腐食に 起因する早期劣化が大きな問題となっている。海岸付近で, 海より 飛来する塩化物イオン量の多い塩害環境下におけるコンクリート は，コンクリート中に塩化物イオンが浸透・蓄積し，鉄筋周辺で短 期間に高濃度となり，鉄筋の腐食を促進させる。したがって，飛来 塩化物イオン量とコンクリートに浸透する塩化物イオン量の関係 や,コンクリート中での塩化物イオン量の分布状況を把握すること は、鉄筋コンクリート構造物の耐久性診断および耐久性設計におい て重要な課題である。しかし, 飛来塩化物イオン量とコンクリート に浸透・蓄積する塩化物イオン量や，コンクリート中での塩化物イ オン量分布の実態についての資料は少ないのが現状である。また， 実験的に様々な条件下で資料を構築するのには長期間を要するた め，解析的にこれらの知見を得ることが望まれている。

従来のコンクリート中への塩化物イオン浸透解析手法では, 見か けの拡散係数を常に一定值として扱い, 外部に面するコンクリート 表面の塩化物イオン濃度を一定とする場合()や，経過時間に応じて

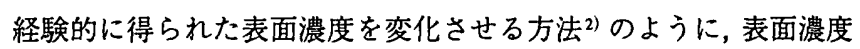
を与える境界条件(ディリクレ型)により，Fickの拡散方程式を解く のが一般的である。しかし,大気中のコンクリートは次第に乾燥し 塩化物イオンの移動に際し，媒体となる水が細孔中から減少するこ とや,水和による細孔変化等により拡散係数は経時的に変化すると
考えられる。また，コンクリート表面の塩化物イオン濃度は,コン クリート中に浸透する塩化物イオン量のみならず, 逆に流失する塩 化物イオン量や，塩化物イオンの拡散性状により決まる值である。 したがって，コンクリート表面において塩化物イオンのフラックス を直接与える境界条件の方が，表面濃度を与える境界条件に比べ， コンクリート中での塩化物イオン量分布や，コンクリート中に流入 出する塩化物イオン量の平衡関係を物理的に正しく表現できる。

そこで本研究は，今まで検討がなされていない飛来塩化物イオン 量とコンクリートに浸透する塩化物イオン量の関係をモデル化し， この関係と洗い流し作用3)考慮して，塩化物イオンのフラックスを 直接与える境界条件を定式化する。次に，コンクリート内部におけ る拡散係数の経年的な低下と, 中性化による影響が示唆される塩化 物イオン濃度のピーク位置の移動を考慮した拡散解析モデルを提案 する。上述の境界条件や拡散解析モデルで生じる諸未知数は，暴露 12 年および暴露 7 年に及ぶ 2 実大暴露実験より得たコンクリート中 の塩化物イオン濃度分布を用いて同定する。そして最後に本研究は, 提案した境界条件と拡散解析モデルを用いてパラメトリックに解析 を行い，既往の研究結果と比較検討し，本解析の有用性を確認する。

\section{2. 境界条件の定式化}

\section{1 飛来塩化物イオン量と浸透塩化物イオン量の関係} 山内らは4),コンクリート表面に付着する塩化物イオンの全てがコ
* 琉球大学工学部環境建設工学科 助手 · 工修

** 琉球大学工学部環境建設工学科 教授 $\cdot$ Ph. D

*** 宇都宮大学工学部建設学科 教授・I博
Res. Assoc., Faculty of Engineering, University of the Ryukyus, M. Eng. Prof., Faculty of Engineering, University of the Ryukyus, Ph. D. Prof., Faculty of Engineering, Utsunomiya University, Dr. Eng. 
ンクリートに浸透するとして，拡散方程式を解いている。これに対 し本研究では, コンクリートに到達する飛来塩化物イオンの全てが コンクリートに浸透するのではなく, 飛来塩化物イオン量と浸透塩 化物イオン量の関係に, Langmuir 吸着理論》の考え方を適用する。

ここでは, 図-1に示すように, コンクリート内部へ浸透する塩化 物イオンは,コンクリート表面で細孔入り口面積に相当する部分(以 後, 有効面積と称す)に到達し, 吸着するものとする。ここで, 塩化 物イオンが吸着している有効面積を占有面積と称し, コンクリート 単位表面積での割合を占有面積率 $\mathrm{n}$ とする。また, コンクリート単 位表面積中の全ての有効面積を飽和面積と称し, コンクリート単位 表面積との割合を飽和面積率 $\mathrm{m}$ (占有面積率 $\mathrm{n}$ の最大值)とする。この 飽和面積率 $\mathrm{m}$ は, 地濃のの測定結果を参考に, 水セメント比毎にコ ンクリート表層部での細孔量を求め, 細孔を円筒と仮定すると, 水 セメント比 $w / c(\%)$ の関数として次式で表される。

$$
m=\frac{\left(0.526\left(\frac{w}{c}\right)-7.61\right)}{57.4} \times 100
$$

なお，コンクリートの細孔量は，中性化によっても変化する。し かし, 本研究では, 中性化による細孔量の変化を定量的に考慮する だけの資料が得られなかったので,中性化による変化は考慮しない。

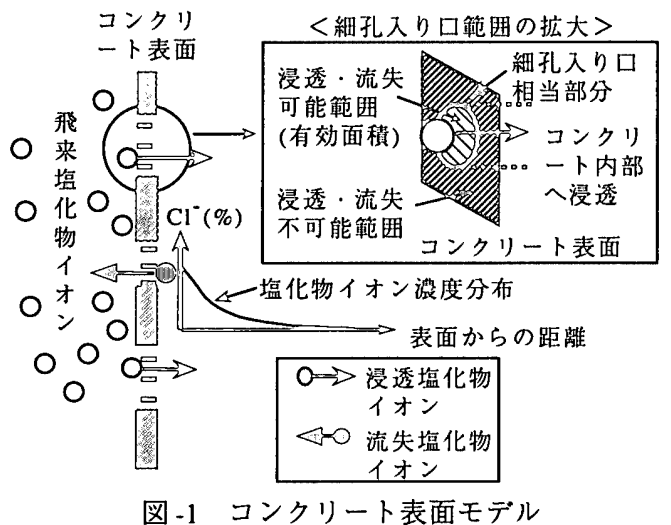

Langmuir吸着理論の考え方と同様に,コンクリート表面における 単位時間あたりの塩化物イオンの吸着量 $\mathrm{A}\left(\mathrm{mg} / \mathrm{cm}^{2 *} \mathrm{sec}\right)$ は, 塩化物イ オンの未吸着な部分, すなわち飽和面積率 $\mathrm{m}$ と占有面積率 $\mathrm{n}$ の差と, 飛来塩化物イオン量 $\mathrm{q}\left(\mathrm{mg} / \mathrm{cm}^{2 *} \mathrm{sec}\right)$ に比例するとして式(2)で表す。 ここで, $\mathrm{k}$ は比例定数である。吸着した塩化物イオンは, 単位時間 に離脱量 Vo $\left(\mathrm{mg} / \mathrm{cm}^{2 *} \mathrm{sec}\right)$ で有効面積より離脱し, 離脱した塩化物イ オンは全てコンクリート中に浸透するものとする。よって, 単位表 面積あたりの浸透塩化物イオン量 $\mathrm{I}\left(\mathrm{mg} / \mathrm{cm}^{2 *} \mathrm{sec}\right)$ は式(3)で表せる。

$$
\begin{aligned}
A & =k q(m-n) \\
I & =n V_{0}
\end{aligned}
$$

吸着量 $\mathrm{A}$ と浸透塩化物イオン量 Iが等しい平衡状態にあるとする と, 式(2),(3)上り次式(4)が得られ，これが飛来塩化物イオン量 $\mathrm{q}$ 浸透塩化物イオン量 Iの関係を表す。

$$
I=\frac{m k V_{0} q}{V_{0}+k q}
$$

\section{2 洗い流し作用の考愿}

筆者の一人は, 洗い流し作用によるコンクリート内部からの塩化 物イオンの流失量を, コンクリート表層における塩化物イオン濃度 に比例するものとして境界条件に考慮している ${ }^{3)}$ 。本研究でも，洗
い流し作用による塩化物イオンの流失を想定し,コンクリート内部 から細孔を介して, 洗い流される塩化物イオン量 $\mathrm{W}\left(\mathrm{mg} / \mathrm{cm}^{2 *} \mathrm{sec}\right)$ は, コンクリート表面における塩化物イオン濃度 Co と飽和面積率 $\mathrm{m}$ の 積に比例するものとして以下のように定式化する。

$$
W=\alpha m C_{0}
$$

ここで, $\alpha$ は単位表面積から単位時間に流失する塩化物イオン量 で流失量 $\left(\mathrm{mg} / \mathrm{cm}^{2 *} \mathrm{sec}\right)$ と称し,この值は雨や結露等で需れ時間が長い 場所は，濡机時間が短い場所よりも見かけ上,この值が大きくなる。 前節で示した浸透塩化物イオン量Iから洗い流し量Wを差し引い た值が，式(6)で表される真の浸透塩化物イオン量It となる。式(6)は， 拡散方程式を解く際に境界条件として与えられる。ここで, 式(6)の 右辺第二項のCoが, 経年にともない増大することより，真の浸透塩 化物イオン量 It は，経年とともに減少する。

$$
I_{t}=\frac{m k V_{0} q}{\left(V_{0}+k q\right)}-\alpha m C_{0}
$$

\section{3. コンクリート中における塩化物イオン拡散解析モデル}

\section{1 拡散解析モデルの概要および数值解法}

本拡散解析モデルは, 従来の拡散解析モデルと比べて次の三つの 特徴をもっている。第 1 は, 飛来塩化物イオン量と浸透塩化物イオ ン量の関係, 洗い流し作用, 水セメント比, 仕上げの効果等も考虑 可能な境界条件を採用していること。第 2 は，中性化の進行にとも ない塩化物イオン濃度のピーク位置がコンクリート表面から内部側 に移動することわを考慮していること。さらに，第3は，コンクリー トの乾燥や, 水和の進行により塩化物イオンの拡散の媒体となる細 孔中の水分が減少し，拡散係数が低下寸ることを考虑していること である。以下に上述の三項目を満足する拡散解析モデルを示す。

塩化物イオンのコンクリート中での拡散性状を表す非定常拡散 方程式を式(7)に示す。ここで，コンクリート表面では，フラックス It の境界条件を与え，他方の境界ではフラックス0とした。初期条 件はコンクリート打設時に既に存在している塩化物イオン量C,を与 える。なお， $\mathrm{t}$ は経過時間， $\mathrm{x}$ はコンクリート表面からの距離とする。

$$
\frac{\partial c}{\partial t}=\frac{\partial}{\partial x}\left(D \frac{\partial c}{\partial x}\right)
$$

初期条件: $\left.\quad c\right|_{t=0}=C_{i}$

境界条件： $\left.I_{t}\right|_{x=0}=\frac{m k V_{0} q}{\left(V_{0}+k q\right)}-\alpha m C_{0} \quad,\left.\quad \frac{\partial c}{\partial x}\right|_{x=\text { end }}=0$

コンクリートの塩化物イオンに対する拡散係数は, 図-2に示すよ うに, 表面から中性化にともない塩化物イオン濃度のピークが形成 される位置まで，見かけの拡散係数を初期拡散係数Do $の \beta$ 倍と大 きくした。また, ピーク濃度位置以媣の見かけの拡散係数は, 初期 拡散係数から経過時間とともに指数的に減少するものとした。コン クリート表層部で中性化が進行していることは，その中性化深さの 範囲においてコンクリートがある程度乾燥していることが条件とな ると考えられる。したがって，この範囲での塩化物イオンの浸透は， 濃度拡散のみならず, 吸水時に移流をともない内部への浸透速度が 増すものと考えられる。よって，本研究では，見かけの拡散係数を $\beta$ 倍と大きくする事を便宜的に計算上の仮定として導入している。 なお，中性化や乾湿の影響を受ける表層部の塩化物イオン拡散解析 モデルに関しては，さらなる検討が必要であると考える。 


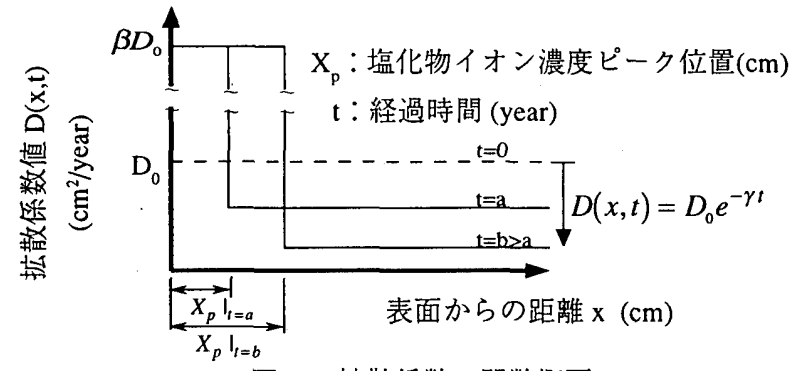

図 -2 拡散係数の関数概要

以上より, 拡散係数は, 位置 $\mathrm{x}$ と時間 $\mathrm{t}$ の関数となり, 次式で表 せる。ここで, $\beta$ は拡散係数の増大係数, $\gamma$ は拡散係数の低減係数 と称す。

$$
\begin{array}{ll}
D(x, t)=\beta D_{0} & \left(\mathrm{x}<\mathrm{x}_{\mathrm{p}}\right) \\
D(x, t)=D_{0} e^{-\gamma t} & \left(\mathrm{x} \geqq \mathrm{x}_{\mathrm{p}}\right)
\end{array}
$$

$\mathrm{x}_{\mathrm{p}}$ は塩化物イオン濃度のピーク位置を表す。このピーク位置は， 暴露実験》の実測結果において, 岸谷式で計算される中性化深さの約 1.5 倍の深さであった。よって, 本研究では $x_{p}$ を岸谷式で計算される 中性化深さの 1.5 倍と仮定して次式で表す。

$$
\begin{array}{ll}
x_{p}=1.5 \times \frac{\left(\frac{w / c}{100}-0.25\right) \sqrt{t}}{\sqrt{0.3\left(1.15+3.0 \frac{w / c}{100}\right)}} & (\mathrm{w} / \mathrm{c} \geqq 60) \\
x_{p}=1.5 \times\left\{0.373\left(4.6 \frac{w / c}{100}-1.76\right) \sqrt{t}\right\} & (\mathrm{w} / \mathrm{c} \leqq 60)
\end{array}
$$

初期拡散係数Doは, 異なった温度について, 水セメント比毎の值 を文献 ${ }^{8)} り$ 得て, 以下の式で近似した。

$$
\begin{aligned}
& D_{0}=0.0343 e^{0.077 w / c} \\
& D_{0}=0.0137 e^{0.085 w / c}
\end{aligned}
$$

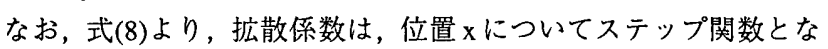
るので, 式(7)に拈いては，拡散係数を定数項として扱える。

本解析では, 式(7)の数值解析手法として有限要素法を採用した。 式(11)に解析対象領域全体の有限要素式を示す。

$$
[K]\{\phi\}+[C]\left\{\frac{\partial \phi}{\partial t}\right\}=\{F\}
$$

ここで, \{申\}は節点塩化物イオン濃度ベクトル, $[\mathrm{K}]$ は拡散項係数行 列, [C]は時間項係数行列, \{F\}は境界条件による既知項で，一般に流 束ベクトルと呼ばれる。

有限要素法により式(11)は空間に関しては離散化されているが, 時間に関しては離散化されていない。そこで, 時間に関する離散化 手法として $\theta$ 法(差分陰解法)を用い，これを式(12)に示す。今回は， 安定性の観点から $\theta$ の值を 0.52 とし, 時間刻みは 0.01 年, 空間刻み は $0.25 \mathrm{~cm}$ とした。

$$
\left(\theta[K]+\frac{1}{\Delta t}[C]\right)\{\phi(t+\Delta t)\}=\left(-(1-\theta)[K]+\frac{1}{\Delta t}[C]\right)\{\phi(t)\}+\{F\}
$$

\section{2 未知数の同定手法}

前節で示した拡散解析手法では, 離脱量 Vo, 比例定数 $\mathrm{k}$, 流失量 $\alpha$ ，拡散係数の增大係数 $\beta$ および経年低減係数 $\gamma$ の 5 值が未知数と なる。未知数Vo, $\mathrm{k}$ は, 飛来塩化物イオン量 $\mathrm{q}$ と浸透塭化物イオン 量Iの間で式(4)で表される関係を満たさなければならない。そこで， 未知数 $\mathrm{Vo}, \mathrm{k}$ を含む浸透塩化物イオン量 $\mathrm{I}$ 末知数とし, Vo, kの 代わりに，I值を同定する。よって，全未知数は 4 個となり，この 4
個の未知数を暴露実験データを用いて修正シンプレックス法》にて同 定する。なお，未知数 Vo, $\mathrm{k}$ は，同定された浸透塩化物イオン量 I が, 飛来塩化物イオン量と式(4)の関係を満たすように決定する。こ れに関しては，次節に記述する。

修正シンプレックス法では, 塩化物イオン濃度分布の解析仮定值 $f\left(x_{i}, t, I, \alpha, \beta, \gamma\right)$ が, 暴露実測値 $g\left(x_{i}, t\right)$ との間に式(13)で表す応答関数 $\mathrm{R}$ を最小とするように, 4 個の未知数 $(I, \alpha, \beta, \gamma)$ を求める。

$$
R=\sum_{i}^{n}\left[g\left(x_{i}, t\right)-f\left(x_{i}, t, I, \alpha, \beta, \gamma\right)\right]^{2}
$$

ここで, $\mathrm{x}_{\mathrm{i}}$ はコンクリート中での位置を表し $\mathrm{t}$ は暴露開始後の経 過時間を表す。

\section{3 実大暴露試験体概要および諸未知数の同定結果}

同定に用いる塩化物イオン濃度分布の暴露実験データは, 沖縄県 本部町備瀬の海岸沿いに建設され，暴露 12 年（平成 8 年現在）を経 過した実大暴露試験体》) と, 沖綿県国頭村辺土名の海岸沿いに建設 され，暴露 7 年（平成 8 年現在）を経過した実大暴露試験体 ${ }^{10}$ 上り 得たデータである。両実大暴露試験体上では土研式飛来塩分補集器

\begin{tabular}{|c|c|c|c|c|c|c|c|c|}
\hline & \multirow{2}{*}{$\begin{array}{r}\mathrm{w} / \mathrm{c} \\
(\%)\end{array}$} & \multirow{2}{*}{$\begin{array}{c}\text { 細骨材率 } \\
(\%)\end{array}$} & \multicolumn{4}{|c|}{ 単位重量 $\left(\mathrm{kg} / \mathrm{m}^{3}\right)$} & \multirow{2}{*}{$\begin{array}{c}\text { スラング } \\
(\mathrm{cm})\end{array}$} & \multirow{2}{*}{\begin{tabular}{|l} 
空気量 \\
$(\%)$
\end{tabular}} \\
\hline & & & 水 & セメント & 紐骨材 & 粗骨材 & & \\
\hline 䚚瀬 & 63 & 51.5 & 183 & 291 & 937 & 900 & $18 \pm 2$ & 4 \\
\hline 辺土名 & 62.5 & 49.6 & 184 & 295 & 877 & 929 & $18 \pm 2$ & 4 \\
\hline
\end{tabular}
を用い，四方位の飛来塩化物イオン量の測定を行っている。

表-1に両実大暴露試験体のコンクリート調合を示し, 表-2には両 実大暴露試験体の各方位における過去 2 年間の平均飛来塩化物イオ ン量を示す。また，表-3には両実大暴露試験体の各方位におけるコ ンクリートの中性化媣ざ示す。図-3(a)には備瀬実大暴露試験体の 北 - 南側, 図-3(b)には辺土名実大暴露試験体北西 - 南東側に面した コンクリート中の塩化物イオン量分布を示す。図中の縦軸は塩化物 イオン量を全塩分で求め, コンクリート重量比で表示している。横 軸はコンクリート表面からの距離で，北および北西を起点に表す。

表 -1 実大暴露試験体のコンクリート調合

表-2 飛来塩化物イオン量 単位: $\left(\mathrm{mg} / \mathrm{cm}^{2 *}\right.$ year $)$

\begin{tabular}{|c|c|c|c|c|c|}
\hline \multicolumn{4}{|c|}{ 備瀬 } & \multicolumn{2}{c|}{ 辺土名 } \\
\hline 北側 & 東側 & 南側 & 西側 & 北西側 & 南東側 \\
\hline 28.6 & 11.5 & 6.98 & 7.22 & 92.8 & 2.58 \\
\hline
\end{tabular}

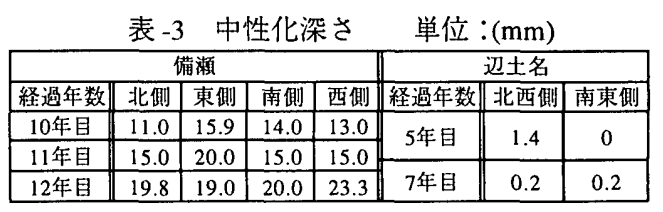

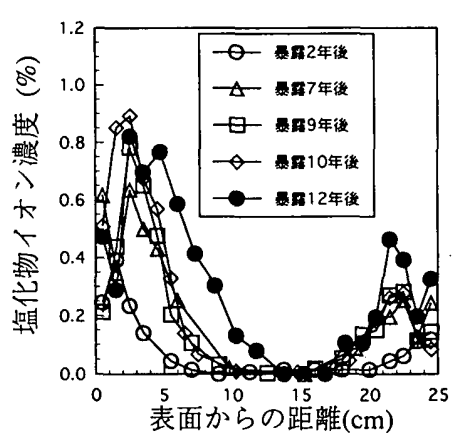

(a)備瀬

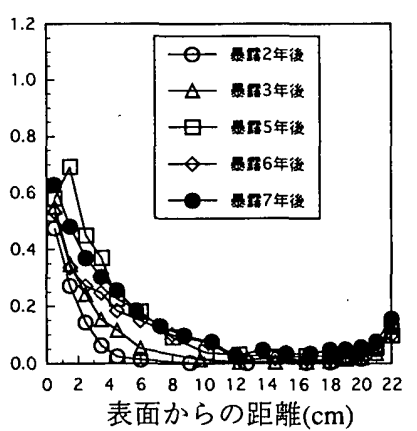

(b)辺土名
図 -3 実大暴露試験体塩化物イオン濃度分布 
表-3および図-3より，中性化の進行している備瀬実大暴露試験体 では, 塩化物イオン濃度のピーク位置がコンクリート内部側に移動 している。また, 中性化が進行していない辺土名実大暴露試験体で は, 塩化物イオン濃度のピーク位置がコンクリート表面にあること が分かる。辺土名実大暴露試験体は，屋根スラブが建設されてなく， かつ，強風時には波しぶきが直接かかる。したがって，コンクリー 卜表層部が需れている時間が多く，備瀬実大暴露試験体に比べ中性 化が進行しにくいものと考えられる。

コンクリート表面と塩化物イオン濃度のピーク位置間の塩化物イ オン濃度分布に関しては, コンクリート表面で下がる場合や，また， その表面濃度がピーク濃度とほほ等しい場合もあり，その分布には 規則性が見られない。そこで, 実大暴露試験体の塩化物イオン濃度 分布を同定用のデータとして用いる場合には，コンクリート表面と 濃度ピーク位置との間の塩化物イオン濃度は, ピーク位置における 塩化物イオン濃度と同じものとした。その結果, 解析により得られ るコンクリート表面と濃度ピーク位置間の塩化物イオン濃度は高め に評価され，設計等に用いる際に安全側となる。なお，辺土名実大 暴露試験体の塩化物イオン濃度分布を同定用のデータとして用いる 場合, 中性化がほとんど進んでいないことから， $\mathrm{x}_{\mathrm{p}}=0$ とし，拡散係 数の增加係数 $\beta$ を除く 3 未知数を同定した。表 -4 に同定した諸未知 数をまとめて示す。

図-4 は同定により得られた浸透塩化物イオン量Iと, 対応する飛 来塩化物イオン量 q との関係を示す。これより，飛来塩化物イオン 量がある值より多くなると浸透塩化物イオン量の増加は, 頭打ちと なることが分かる。ここで, 両実大暴露試験体の水セメント比は $63.0 \%$ であり,式(1)より飽和面積率 $\mathrm{m}=44.5 \%$ となる。これを考慮し， プロット点を式(4)にて近似すると, $\mathrm{Vo}=42.1\left(\mathrm{mg} / \mathrm{cm}^{2 *} \mathrm{year}\right), \mathrm{k}=3.51$ を得る。近似曲線を図中に示す。近似曲線はプロット点を良く表し ており，Langmuir吸着理論の考え方を適用した式(4)は，飛来塩化物 イオン量と浸透塩化物イオン量の関係を表す式として適切であると 言える。なお，両実大暴露試験体の建設された環境が沖縄県の海岸 沿いで，ほほ同じ環境であることから，Vo， $\mathrm{k}$ 值は両実大暴露試験 体では変わらないものと考える。なお, 離脱量 Vo と比例定数 $\mathrm{k}$ の値 は,コンクリートの設置環境および水セメント比に影響される可能 性がある。しかし，この点に関する資料が不足のため, 本研究では, 陸上大気中に設置されたコンクリートは,水セメント比に関わらず, 前述の $\mathrm{Vo}=42.1\left(\mathrm{mg} / \mathrm{cm}^{2 *} \mathrm{year}\right), \mathrm{k}=3.51$ の值を用いる。

表 -4 より, 流失量 $\alpha$ は, 屋根スラブの建設された備瀬実大暴露試 験体では小さく, 屋根スラブの無い辺土名実大暴露試験体では大き い。また, 方位別では，北側が大きく，南側で小さい傾向がある。こ れは，日射や結露時間の関係で，南側に比べ北側が濡れ時間が長い ことに対応していると考えられる。拡散係数の経年低減係数 $\gamma$ は, 濡れの多い辺土名実大暴露試験体の北西側では小さく，濡れの少な い備瀬実大暴露試験体の南側および西側で比較的大きな值となって いる。これは, 表面が需れることによりコンクリート内部の細孔中 の水分が乾燥しにくくなり，この水分を媒体とする塩化物イオンの 拡散効果が経年後も低下しにくいためと考えられる。

本解析では, 雨掛かりのある場合の流失量 $\alpha$ および拡散係数の低 減係数 $\gamma$ を辺土名実大暴露試験体の平均值, $\alpha=0.580, \gamma=0.089$ と し, 雨掛かりのない場合の各係数の值を備瀬実大暴露試験体の平均
表 -4 同定した未知数一覧

\begin{tabular}{|c|c|c|c|c|c|c|}
\hline 7 & I & $a$ & $\bar{\beta}$ & $\gamma$ & 平均 $a$ & 平均 $\gamma$ \\
\hline 備㖽北 & 14.5 & 0.519 & 20.6 & 0.121 & \multirow{4}{*}{0.389} & \multirow{4}{*}{0.155} \\
\hline 侕瀬東 & 10.2 & 0.446 & 20.6 & 0.170 & & \\
\hline 供瀬南 & 4.68 & 0.263 & 20.5 & 0.169 & & \\
\hline 備瀬西 & 7.21 & 0.330 & 21.2 & 0.160 & & \\
\hline 辺土名北西 & 15.5 & 0.771 & 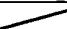 & 0.032 & \multirow{2}{*}{0.580} & \multirow{2}{*}{0.089} \\
\hline 辺土名南東 & 2.05 & 0.389 & & 0.146 & & \\
\hline
\end{tabular}

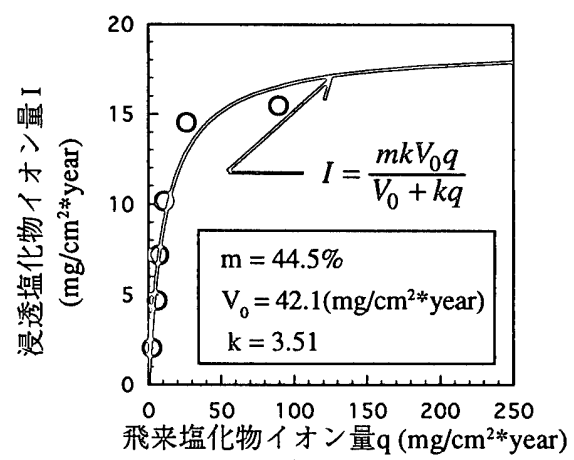

図 -4 浸透塩化物イオン量と飛来塩化物イオン量の関係

值の $\alpha=0.389, \gamma=0.155$ とする。また, 増加係数 $\beta$ は備瀬の各方位 で約 21 と一定の值が得られているので, この值を用いる。

\section{4. 解析結果の検討}

実際の環境下に設置されるコンクリート中への塩化物イオン浸透 は, 雨掛かりの有無や仕上げの有無により影響を受ける。ここでは, これらの要因を含む問題に対する本解析の適用性について定性的に 考察する。また, 仕上げの無いコンクリート中における塩化物イオ ン量分布については, 本解析結果と他者の実測結果との定量的な比 較を試みる。なお, 他者の害測值は, 各参考文献の図から読み取っ た值である。

\section{1 雨掛かりの影敳}

川上"1は，円柱のモルタルおよびコンクリート供試体を海岸付近 にフード付き,あるいはフードなしで約 3 年10个月間暴露を行ってい る。その結果, 雨掛かりの無いフード付きの暴露供試体の方が, フー ド無しの場合に比ベモルタルおよびコンクリート中に浸透する塩分 量が多くなることを示している。図-5に海岸から $100 \mathrm{~m}$ 離れた地点 に,フード付きやフードなしで暴露した $\mathrm{w} / \mathrm{c}=65.0 \%$ のコンクリート 供試体の塩化物イオン濃度の分布値を示す。

筆者等の調査によれば, 飛来塩化物イオン量は, 海岸の状況, 地 形の状態に依存しているが, 海岸から約 $100 \mathrm{~m}-150 \mathrm{~m}$ の範囲において 飛来塩化物イオン量は $0.75 \sim 2.64 \mathrm{mg} / \mathrm{cm}^{2 *}$ yearであった ${ }^{22) 。 そ こ て ゙, ~}$ 飛来塩化物イオン量を上述の中間値の $1.7 \mathrm{~g} / \mathrm{cm}^{2 * *}$ yearとし, 海岸から $100 \mathrm{~m}$ 離れた地点で, 3 年 10个月経過した $\mathrm{w} / \mathrm{c}=65.0 \%$ のコンクリート 中の塩化物イオン分布を, 雨掛かりのある場合と無い場合で解析し, その結果を図 -5 に示す。

ここで, 雨掛かりのない場合は，ある場合に比べて表層側で濃度 が高く,コンクリート内部での濃度の低下率が大きい。これら実測 値の特徵を本解析はとらえており, 本解析は, 洗い流し作用を表し ていると言える。但し, 本解析の洗い流し効果は, 川上の実測結果 に比べると小さい。本解析では，雨掛かりのない場合の流失量とし て, 屋根スラブの建設された備瀬実大暴露試験体の平均值を用いて 
いる。しかし, 備瀬実大暴露試験体が実大サイズであるため, フー ドに比べると雨水の遮蔽効果が少ない事や, 沖縄の海岸では多湿で あるため, 結露による洗い流しが起こりやすい。したがって, 本解 析で用いた流失量は，フード付きの条件下に適用するには大きな值 であるため，上述の結果になったものと推察される。

\section{2 仕上げ材(複層仕上げ塗材)の塩化物イオン遮蔽効果の影響}

池永 ${ }^{13)}$ は, 複数の塗膜系仕上げ材の経時劣化とその塩分遮蔽効果 を広範囲の調查と実験により明らかにし,これを用いて塗膜系仕上 げの施されたコンクリート中への塩分浸透解析を行っている。その 解析手法は, 文献3)で与えられたコンクリート表面濃度に, 塗膜系 仕上げの塩分遮蔽効果とその経時劣化を考慮して拡散方程式を解い たものである。

本解析では，コンクリート表面の塩化物イオンの流入出に対して 仕上げの効果が合理的に評価できるよう，仕上げが施されれば塩化 物イオンの浸透する細孔が減少し, その仕上げが劣化すれば次第に 塩化物イオンの浸透する細孔が増加するものと考え, 仕上げの塩分 遮蔽効果を飽和面積率 $\mathrm{m}$ の変化とみなして考える。仕上げの効果を 考慮した飽和面積率 $\mathrm{m}_{\mathrm{s}}$ を式(14)に示す。仕上げを施した直後におい

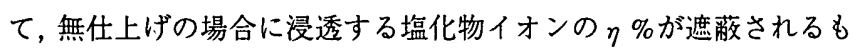
のとし, 仕上げの経時劣化は, 池永の結果から劣化度 $R=1.18 y^{1.46}$ を用いた。ここで, $\mathrm{y}$ は経過年数であり, 経過年数が増えて劣化度 Rが100\%をこえた場合には, 劣化度 Rは，100\%の值で一定とした。

$$
m_{s}=m\left(1-\frac{\eta}{100}\left(1-\frac{R}{100}\right)\right)
$$

以下に, 遮蔽効果率 $\eta=90.0 \%$ とし, 池永の求めた劣化度を考虑 し, 海岸から $100 \mathrm{~m}$ 位置における $\mathrm{w} / \mathrm{c}=63.0 \%$ のコンクリートに仕上 げを施す場合と, 施さない場合の塩化物イオンの浸透状況を本解析 により比較する。ここで, 飛来塩化物イオン量の值は $\mathrm{q}=2.58(\mathrm{mg} /$ $\mathrm{cm}^{2 *}$ year)を用いる。この值は, 文献 12)において, 海岸から $100 \mathrm{~m}$ 前 後離れた場所での最大飛来塩化物イオン量に近い值である。また, 環境条件として雨掛かりがあり, 沖縄県に設置されたコンクリート を対象とし, 初期拡散係数Doには式(10-a)を用いる。中性化速度は, 仕上げのない場合には岸谷の式(9-a)にて求た。仕上げのある場合の 中性化速度比は, 仕上げを施さない場合を 1.0 とすると, ペイント

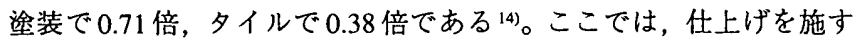
場合の中性化速度比は，施さない場合の 0.5 倍とした。

図-6は，コンクリート中の塩化物イオン濃度分布を仕上げを施す 場合と，施さない場合で比較したものである。仕上げを施すと中性
化が低減されるため, 内部への塩化物イオン量の移動が少なく，ま た, 拡散係数の值が大きい暴露開始当初の時期に, 塩化物イオンが 遮蔽されるため塩化物イオンの内部への移動量が少ない。これらの 理由により，仕上げがないと限界腐食量をはるかに超える塩化物イ オン濃度となっているが, 仕上げを施すことにより，かぶり $4 \mathrm{~cm} に$ おいて経過10年目ではまだ限界塩分量を越えない塩化物イオン濃度 となっている。しかし，この飛来塩分環境下では，この仕上げを施 しても, 経過 30 年目で, かぶり $8 \mathrm{~cm}$ 位置でも限界腐食量を超える。

図-7は，塩化物イオン量測定に用いられるコア $(\phi 10 \times 15.0 \mathrm{~cm})$ 中にふくまれる蓄積塩化物イオン量 $(\mathrm{g}) を ，$ 仕上げのある場合とない 場合で比較している。仕上げのある場合, 経過 21 年目までは劣化度 $\mathrm{R}$ に応じた指数的な蓄積塩化物イオン量の増加を示す。経過約 21 年 で完全に仕上げが劣化した以降は，仕上げ無しの場合と同様な収斂 型の増分となる。但し, 仕上げが完全に劣化しても，仕上げを施し た場合は，仕上げ無しの場合に比べて蓄積塩化物イオン量の増分が 少ない。これは，仕上げを施すと中性化が低減されるため，内部へ の塩化物イオンの移動が少なく, 表層部での塩化物イオン濃度が次 第に高くなり(図-6参照), 結果として多くの塩化物イオンが洗い流 しにより流失されるためと考えられる。

図中には同じ飛来塩分環境下にある辺土名実大暴露試験体南東側 の仕上なしコンクリート中の蓄積塩化物イオン量の実測值も示す。 実測値の蓄積塩化物イオン量の経年増加に比べ, 解析值による増分 の方が大きい。この理由は, 本解析においては, 中性化が進行し, 塩 化物イオン濃度のピーク位置が内部に移動する際には, コンクリー 卜表面と塩化物イオンのピーク位置間の塩化物イオン濃度を一定と し, コンクリート表層の塩化物イオン濃度を実際の測定結果より高 く見積っている(3.3節参照) ためである。

\section{3 実測結果との定量的比較}

文献15)では, 各飛来塩分環境下において暴露したコンクリート中 の塩化物イオン量および飛来塩化物イオン量を測定している。その 測定値と, 本解析值の比較を図 -8 に示す。図中に暴露場所, 飛来塩 化物イオン量, 海岸からの距離, 暴露期間をまとめて示し, 飛来塩 化物イオン量の多い順に(a),(b),(c)と並べる。ここで, 初期拡散係数 Doは，沖縄に暴露されている場合は式(10-a)の值を用い，それ以外 の地域に暴露されている場合は式(10-b)の値を用いた。また，文献 15)の暴露状況より，コンクリート表面は雨掛かりするものとした。

図 8 より, 本解析結果は, 異なる飛来塩分環境下および異なる水 セメント比の供試体中の塩化物イオン量分布について, 実測值結果

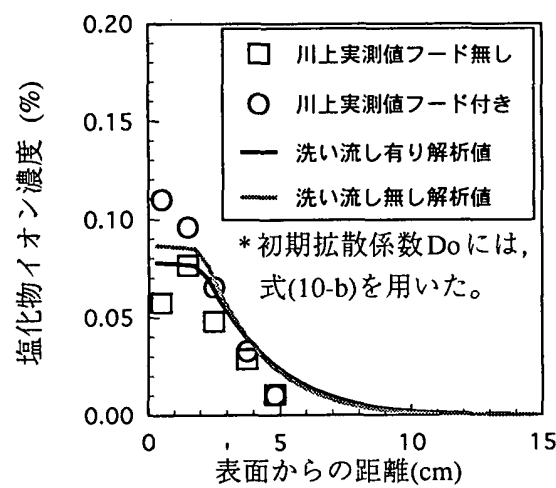

図 -5 洗い流し効果の検討

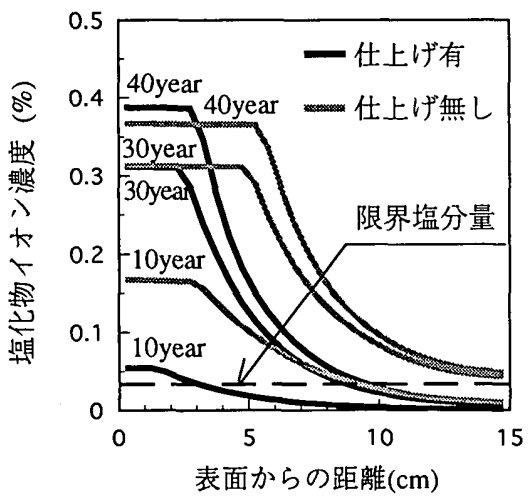

図 -6 仕上げ効果(塩化物イオン濃度分布)

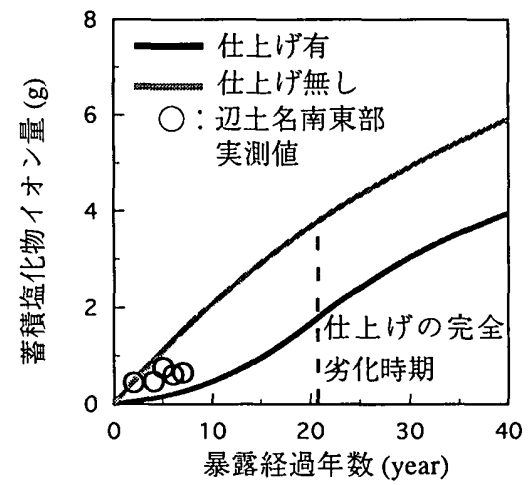

図 -7 仕上げ効果(蓄積塩化物イオン量) 
を良く表している事が分かる。とくに, 実測值において,コンクリー 卜表面近くでは, 水セメント比が異なっても，塩化物イオン濃度が ほほ同じになる傾向があるが，この現象を本解析は表している。

図 -8 に示した実測結果は，暴露期間が 2 年〜 3 年と短い場合であ る。そこで，図-9に暴露 6 年 5 ケ月経過した $w / c=40 \%$ の暴露供試体 のコンクリート中の塩化物イオン量分布の実測値と本解析による值 を示す。図中には, 暴露場所, 飛来塩化物イオン量, 海岸からの距 離, 暴露期間をまとめて示す。この図より，本解析值は，暴露期間 が長い場合でも実測值を良く表している事が分かる。

\section{5. まとめ}

本研究では，異なる環境下における飛来塩化物イオン量とコンク リートに浸透する塩化物イオン量の関係, 洗い流し作用, 水セメン ト比の影響, さらに仕上げの効果等も考虑できる境界条件を提案し た。さらに, 中性化による塩化物イオン濃度のピーク位置の移動や， コンクリート内部における拡散性状の低下を考慮した拡散解析モデ ルを提案し，これをF.E.Mにより解析する方法を示した。なお，モ デル化の過程で生じる未知数は, 暴露 12 年および暴露 7 年におよぶ 実測結果より,修正シンプレックス法にて同定した。この一連の作 業により得られた境界条件および拡散解析モデルを用いて, 異なる 条件下で解析を行い，他の研究成果と比較した。本研究で得られた 知見を以下にまとめる。

1) 飛来塩化物イオン量がある值より多くなると, 浸透塩化物イオ ン量の増加は頭打ちとなる。この飛来塩化物イオン量と浸透塩 化物イオン量の関係は, Langmuir吸着理論の考え方を適用した 式(4)にて表せる。

2) 本解析は, 雨掛かりの有無を流失量 $\alpha$ と拡散係数低減係数 $\gamma$ を 考虑する事により，雨掛かりする場所と，雨掛かりしない場所 におけるコンクリート中の塩化物イオン量の違いを表せる。

3）本解析は，仕上げによる塩分遮蔽効果および仕上げ劣化を飽和 面積率の変化として考慮することにより, コンクリート中への 塩化物イオンの浸透性状を解析的に求める事ができる。

4) 本解析は, 水セメント比および飛来塩化物イオン量の異なる場 合でも，コンクリート中の塩化物イオン分布について，実測値 と良く対応した解析結果を得ることが確認できた。

\section{謝辞}

本研究にあたり，東亜合成株式会社，株式会社小野田の協力を得ました。ま た，4.3節の図-9に関して，試験体は沖縄開発庁 沖縄総合事務局，飛来塩化物 イオン量は建設省土木研究所材料施工部 西崎到 主任研究員より提供頂きまし た。記して感謝の意を表します。

\section{参考文献}

1)たとえば竹田宣典, 迫田恵三, 十河茂幸: 海洋環境下におけるコンクリート 中への塩分浸透に関する研究, 土木学会第44回年次学術講演会講演概要集第 5 部, pp. 268-269,1989.9.

2)たとえば大城武，堀園義昭，谷川伸，永井揵太郎：コンクリート中への塩素 イ、オンの没透に関する実験的及び解析的研究, コンクリート工学年次論文報 告集, Vol.9, No.1,pp. 369-374,1987.6

3）桝田佳寛，友沢史紀，安田正雪，原挔治：コンクリート中への塩化物没透 速度に関する実験, コンクリート工学年次論文報告集, Vol.10, No.1,pp493498,1988.6.

4）山内幸裕, 片脇清士, プレストレストコンクリート構造物の腐食に関する研 究 - 飛沫带におけるコンクリートへの塩分浸透に関する調查結果 -, 土木学 会第 37 回年次学術講演会講演概要集第 5 部, pp.269-270, 1982.9 .

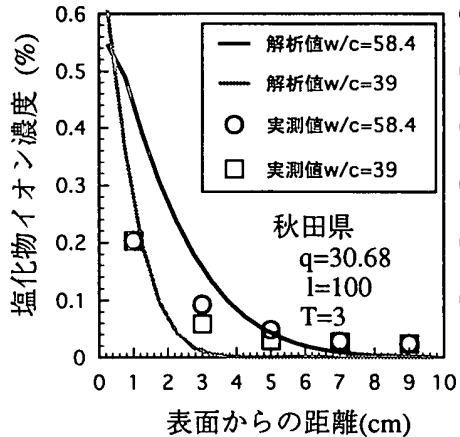

(a)

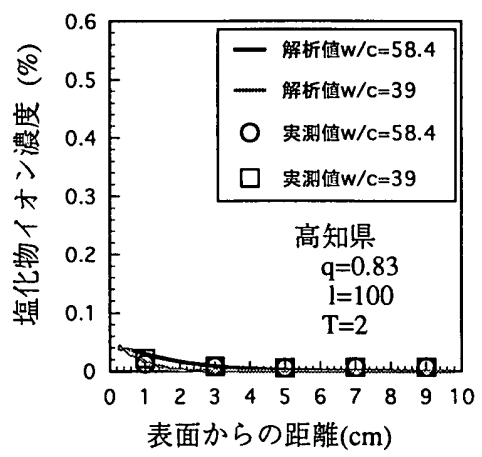

(c)

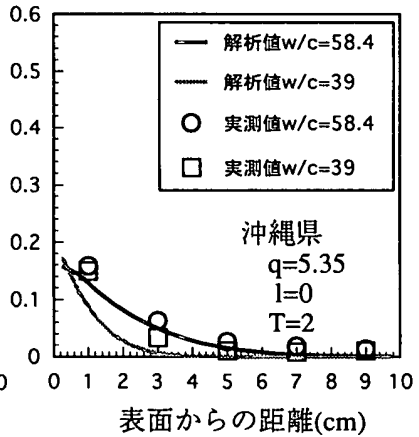

(b)
図-8 実測值との比較 (暴露期間が短い場合)

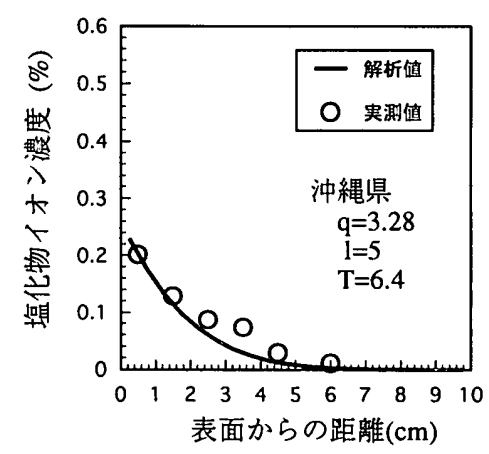

図 -9 実測値との比較 (暴露期間が長い場合)

5) 慶伊富長：吸着，共立出版株式会社, 1965.

6) 地波茂雄，吉田晃：コンクリート表層部の劣化と補修に関する考察，コンク リート構造物の補修工法に関するシンボジウム論文報告集, pp. 23-30,1996.10 7) 谷川伸, 山田義智, 大城武, 川村満紀：擘しい塩害環境下での鉄筋コンクリー 卜構造物の耐久性に関する研究(アクリルコム系防水叙膜の効果), 日本建姀学 会構造系論文集, No.487,pp.11-19,1996.9.

8) 日本建築学会 : 建築工事標準仕様车・同解説 JASS5 鉄筋コンクリート工事, 1986.

9) 大野公一, 石田俊正 : 化学数学, マグロウヒル出版株式会杜, 1992.

10) 大域武，伊部博，近藤忠生，成底佐一郎：塭害環境下における RC構造物の 劣化過程について, コンクリート工学年次諭文報告集, Vol.16, No.1,pp. 947 952,1994.6.

11) 川上英男, 脇敬一: コンクリートへの塩分漫透と垛害環境の評価, 日本建築 学会構造系論文集, No.453,pp. 9-14,1993.11

12) 佐藤旅人, 大城武, 山田䔐智, 桝田佳寛, 清水昭之：沖縄県における飛来塩 分特性，日本建筑学会学術講演梗概集(東海), A,pp. 145-146,1994.9.

13) 池永博威: 塗膜系仕上材の耐候性少化と遮塩性能に関する研究, 日本建築学 会構造系論文集, No.432,pp. 11-18,1992.2.

14）岸谷孝一，西澤紀昭，他：コンクリート構造物の耐久性シリーズ中性化，技 報堂出版，1990.

15) 建設省:建設省総合技術開発プロジェクトコンクリートの的久性向上技術の 開発報告書 $<$ 第一編 $>, 1988$.

(1997年5月 9 日原稿受理, 1997年 7 月 4 日採用決定) 